\title{
GOOGLE CLASSROOM AS LEARNING PLATFORM IN TEACHING WRITING
}

\author{
Ahmad Azhari Yunus \\ Ahmad Syafi'i \\ STKIP Al Hikmah Surabaya \\ Ahmadazhariy08@gmail.com \\ ahmadsyafii20@gmail.com
}

\begin{abstract}
Technology today has played a major role in the field of education especially with the adaptation of World-Wide Web and fast internet networking such as $4 G$ and $5 G$. Since traditional teaching activity is seen not more enough to support the students' learning of English especially in the EFL context where the English are commonly used at school, university, or college educators have combined face to face interaction with an online course in blended learning. The Google Classroom is a networks platform for interaction among teachers and students, collaborate, share and evaluate homework, grades, class discussions, notices, and evaluations. Its objective is to help educators use social media power to customize the classroom for all students. Awareness of the positive potentials of this learning style will allow Google Classroom to introduce a mixed learning approach in the classroom. The post would discuss how Google Classroom facilitates English classroom teaching and learning writing. The argument continues with Google Classroom presentation and the idea of mixed education using Google Classroom. Then it continues with the application of this platform into actual teaching writing context and its outcome. Furthermore, the researchers will also discuss the current and future challenges of Google Classroom in ELT writing for EFL learners as well as teachers
\end{abstract}

Keywords: Google Classroom, EFL, Writing, Blended Learning

\section{INTRODUCTION}

Nowadays, digital technology or ICT in education needs especially in the learning activity is raising up. The advantages of ICT are not only in the circumstances of information, but it also has a big contribution in the educational world through online and offline learning. With technological advances, nowadays learning is no longer connected by space, distance and time. The result of the modernity in developing country is the process of transformation from the conventional learning activity to adapt the online learning activity, because the conventional 
and its limited can unable to support today learning. Online learning appear to carry another strategies in teaching since it offers teachers and learners access to anywhere, anytime "information rich" sources (Kistow, 2011).

Online learning is widely used as a media that supports education particularly in learning today. To bridge the both sides of both conventional face to face interaction and online learning, the blended learning is the briliant method to support this issue. Garrison and Vaughn (2008) define the basic principle of mixed learning as a situation in which direct interaction and online writing interaction are optimally combined so that each ability is incorporated into a specific learning experience that is compatible with the context and intended educational purpose. Many educators all over the area of the world construct their effective learning activity through online platforms in supporting the blended learning.

One of the platforms that used is Google Classroom from Google.com. Google Classroom is a part of Google Suite for Education and officially launched in 2014. As described in www.support.google.com, Google Classroom aims for more productive and meaningful teaching by efficiently managing assignments, increasing collaboration, and improving communication. It is also equipped with various features that enable the teacher to manage class more effectively through Google Mails, Google Docs, Google Drive, Google Slides, and recently, Google Calendar. According to Beal (2017), Google Classroom a tool that facilitates students and teacher collaboration; also, the teacher can make and distribute assignments for students in an online classroom for free. It makes teachers ease to construct groups to share assignments and announcements. Google Classroom can be a platform that makes learners become active participants. Furthermore, Nagele (2017) said that teachers can make effective lessons that are studentcentered, interactive and memorable through Google Classroom, as it offers easyto-use learning tools for students of all categories to work together. As the evidences, many universities in Indonesia used digital technology or ICT as one of their resources in providing teaching and learning to launch the growth of the learning gap in Indonesia. STKIP Al Hikmah Surabaya is one of example of

\section{British, Jurnal Bahasa dan Sastra Inggris}


universities that use online learning, especially in English Education Department. English Education Department of STKIP Al Hikmah Surabaya use the Google Classroom as virtual classroom learning site for several courses, like writing, listening, and other extended courses. For writing courses, the TCL have greatly outcome in writing improvement. Google Classroom enables teachers to create lessons, provide students with the ability to distribute the assignment, submit feedback quickly, immediately and paperless also able to see everything in a single area. In the form of active and interactive learning packed in collaborative learning, Google Classroom also provides students with space.

\section{RESEARCH METHOD}

This research implemented descriptive qualititative using library research approach. Qualitative research result data in the form of notes or descriptive data in the online text investigated. The data gathered mainly focused on the use of Google Classroom in the teaching context and its outcome, the advantages of Google Classroom in ELT, Google Classroom for EFL learners, Google Classroom and writing and current and future challenges of using Google Classroom. Each data objectively and systematically analyzed and presented descriptively.

\section{FINDING AND DISCUSSION}

\section{The Use of Google Classroom in the Teaching Context and Its Outcome}

Via Google Classroom the teacher will improve their productivity and meaningfully teaching by efficiently managing assignments, increasing collaboration, and improving communication. In order to have class at Google Classroom, teachers should create account first at classroom.google.com and sign up as a teacher and able to make their subject class.

Create a class

1. Go to classroom.google.com.

2. On the Classes page, click Add $+>$ Create class. 


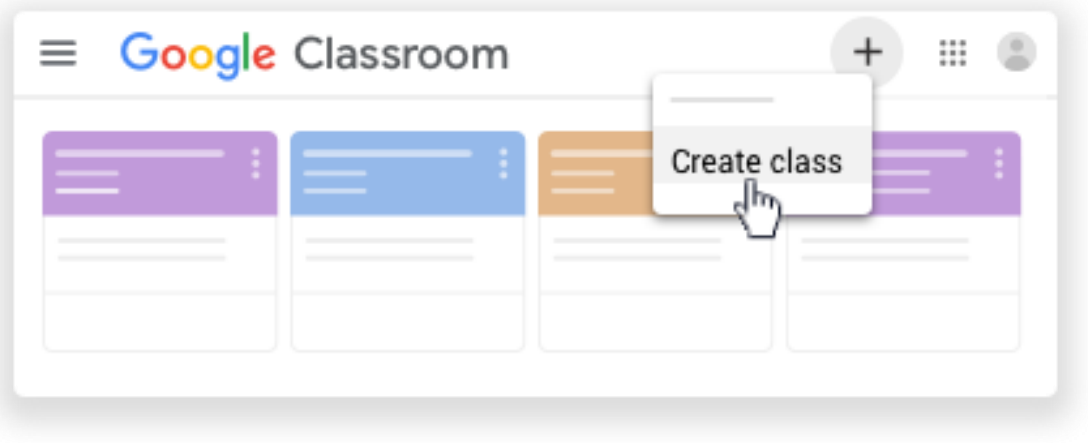

Figure 1 Main Page

3. Enter the class name.

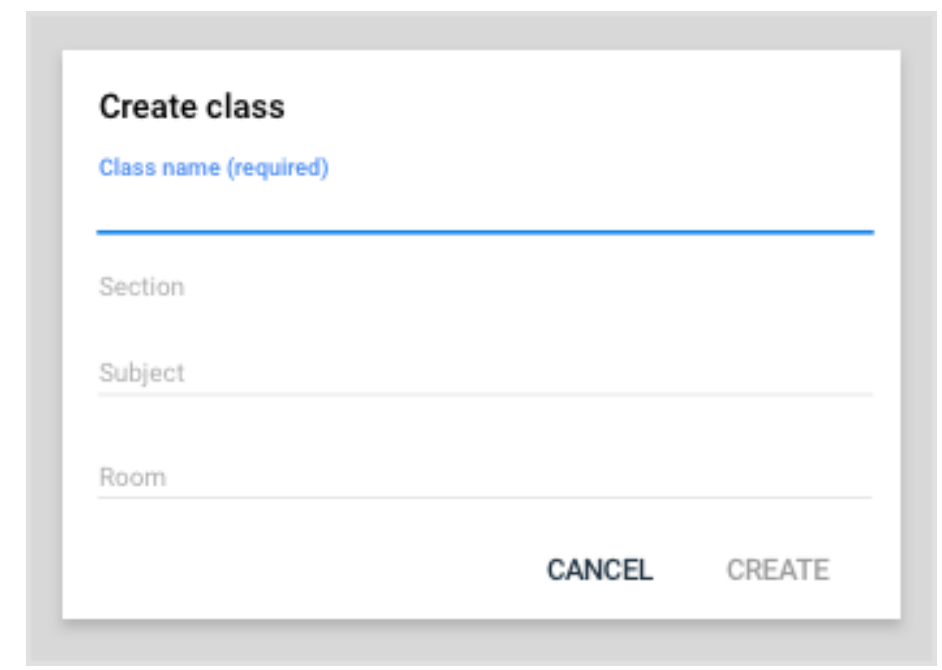

Figure 2 Classroom Desrcription

4. (Optional) To enter a short description, grade level, or class time, click Section and enter the details.

5. (Optional) To add a subject, click Subject and enter a name, or click one from the list that appears when teacher enter text.

6. (Optional) To enter the location for the class, click Room and enter the details.

\section{Click Create.}

Students role here just follow the teacher class by inserting code from their teacher after login by their Gmail. It is also equipped with various features that enable the teacher to manage class more effectively through Google Mails, Google Docs, Google Drive, Google Slides, and recently, Google Calendar.

\section{British, Jurnal Bahasa dan Sastra Inggris}


According to Beal (2017), Google Classroom a tool that facilitates students and teacher collaboration; also, the teacher can create and distribute assignments for students in an online classroom for free. By this context Google Classroom will role as the learning media in teaching and learning writing activity, with following the learning process there are: Giving announcement, Assignment, Class discussion, Feedbacking, Attending, Scoring or evaluating.

\section{Giving Announcement}

An announcement is made, and each student receives an email notification of the announcement. The ad appears on the stream page in the class. To edit or delete an ad, click on the three folded dots in the upper right corner of the ad window.

Keeping students informed is one of the most important things as a teacher. In Google Classroom, if a teacher wants to quickly contact the entire class without sending an email, the teacher can make an announcement. Here's how:

1. Enter the class and go to the Stream tab, if it is not already displayed.

2. Click Announcement.

3. Enter a detailed announcement.

4. To attach a file, video or link to an ad, click the corresponding icon, as described below:

- Paper clip: this option attaches the file to the destination.

- Drive Google Drive: this option also attaches the file to the destination, but transfers the teacher directly to his / her Google Drive to find the file.

- YouTube YouTube play button: This option allows the teacher to attach a YouTube video to the assignment.

- Link: The teacher can click the link button in the chain to insert the external URL into the destination.

5. If the teacher wants to send an announcement to other classes, click on the class name below and select additional classes.

6. When the teacher is finished, their announcement may look something like shown in Figure 1. Click Post.

\section{British, Jurnal Bahasa dan Sastra Inggris}




\section{Class Discussion}

1. Open Spread Sheet + Discussion Board + Start Discussion Board.

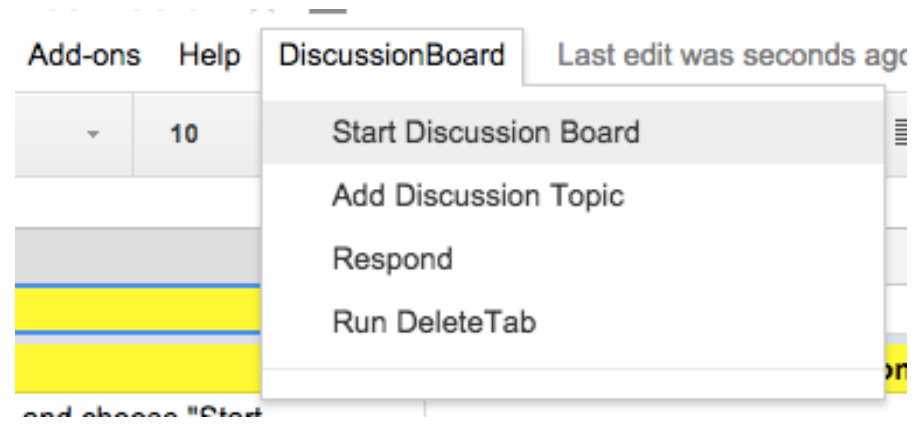

Figure 3 Making Discussion Board

2. Enter the Discussion Name

3. Discussion Tab

Rename the following cell as teacher needed for

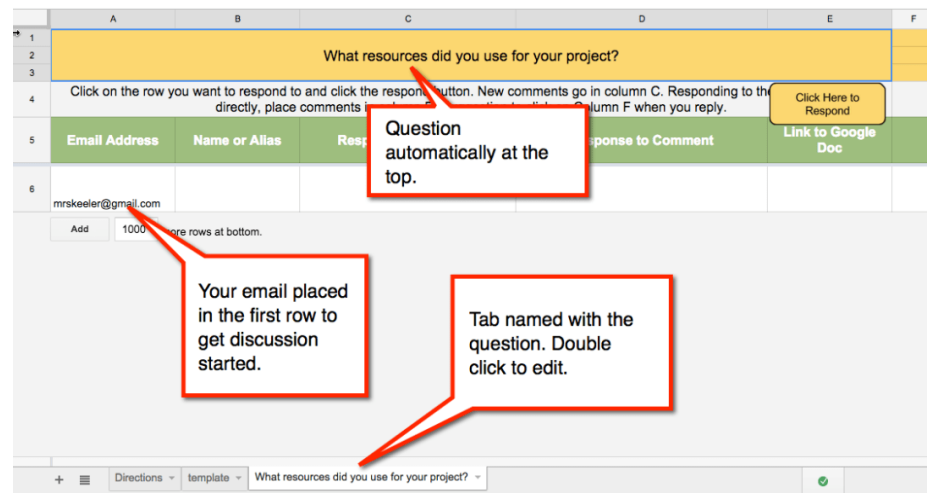

Figure 4 Adding discussion topic

4. Choose "Add Discussion Topic."

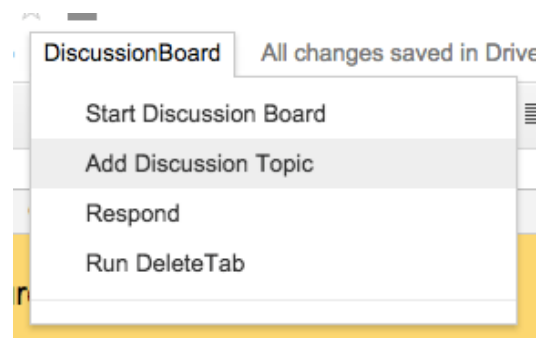

Figure 5 Adding discussion topic

British, Jurnal Bahasa dan Sastra Inggris 
5. Attach in Google Classroom

Create a new assignment and click on the Google Drive icon.

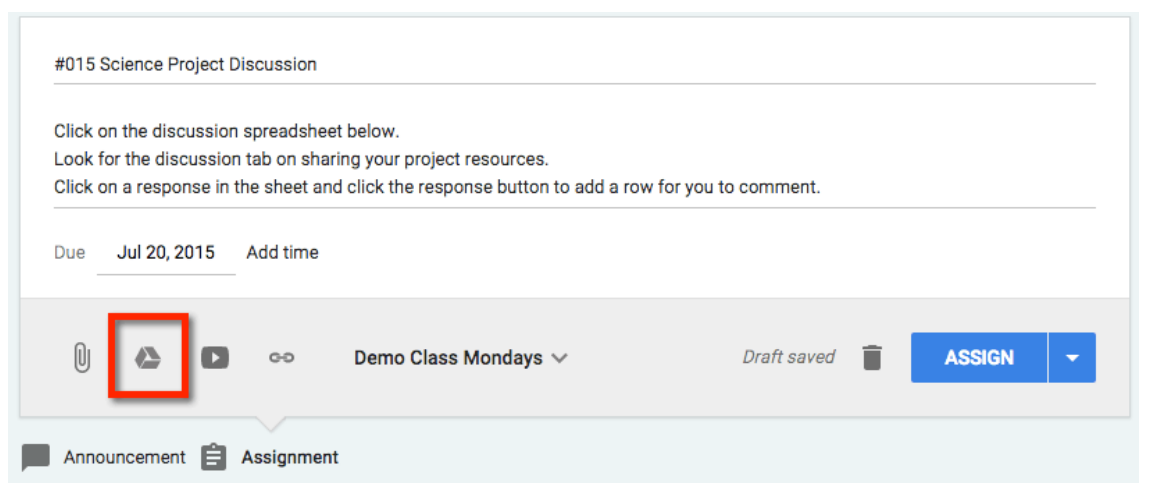

Figure 6 Attaching Google Classroom

6. Browse their Google Drive for the discussion board teacher created.

Change the default from students can view to students can edit file.

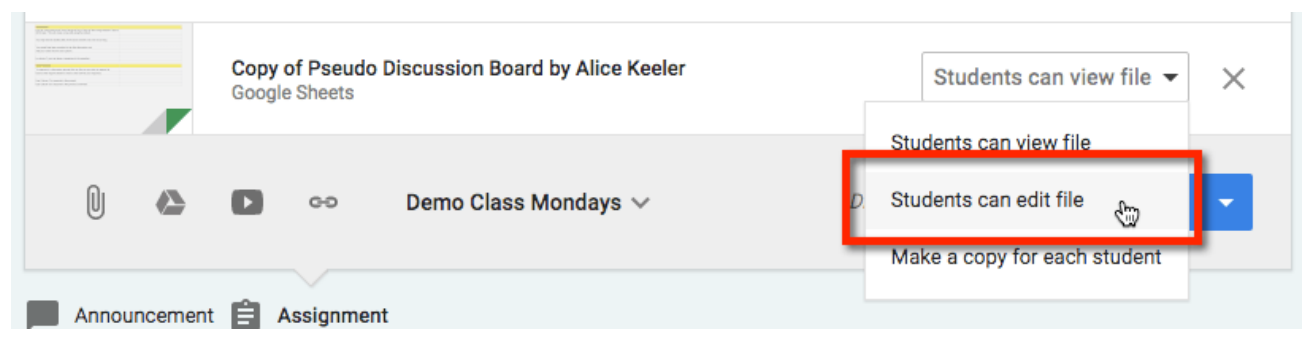

Figure 7 Making students to access the board

\section{Feedbacking}

Inside of feedbacking in google classroom there two ways to do, there General Comment and Private comment

General Comment can be applied If teacher enter the same comment for many students, the teacher can save the comment to use later. The comment bank is tied to the Google Account, so the teacher can access it from any computer.

1. Open a student assignment in the grading tool.

2. Highlight the passage which want to be commented on and click Add a comment Add comment. 


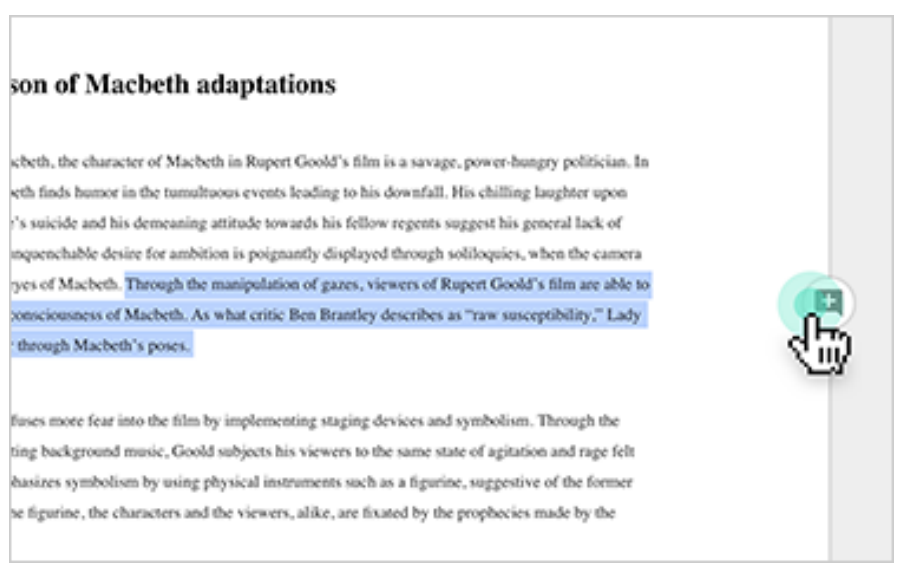

Figure 8 Feedback

3. Add a comment

4. Enter their comment and click Comment.

Private comment can be optioned by teacher can add private comments for a student. Private comments can't be edited or deleted after teacher post them.

1. Open a student assignment in the grading tool.

2. Click Grading

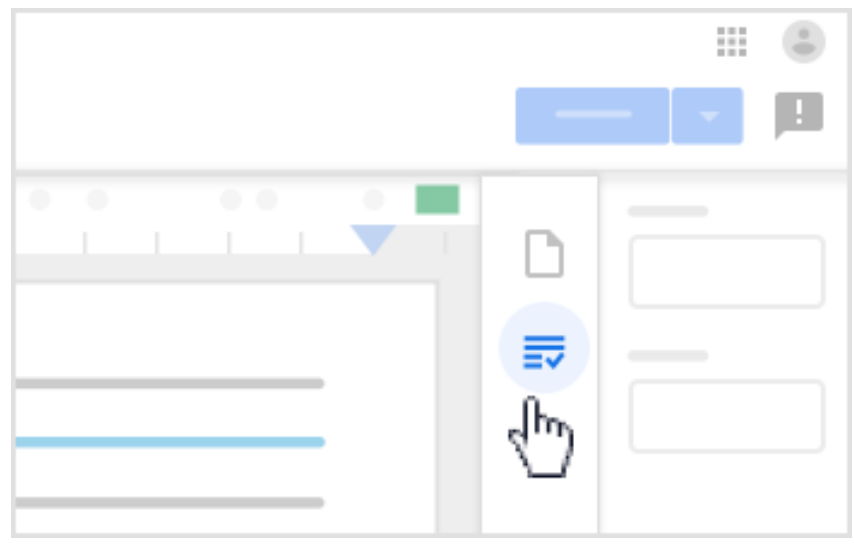

Figure 9 Private Comment

3. Under Private comments, enter their comment.

4. Click Post.

\section{Attending}

Track student attendance with a Google Sheet.

\section{British, Jurnal Bahasa dan Sastra Inggris}




\section{Scoring or Evaluating}

1. A posted assignment in Google Classroom with student work. The work categorized as not yet submitted, but there does need to be student work attached or it won't recognize the assignment.

2. The Goobric Chrome Extension. The teacher only have to download this once.

3. The Doctopus Add-On for Google Sheets. Click "Add-ons" $\rightarrow$ "Get addons" on the file menu. Again, you only have to do this once.

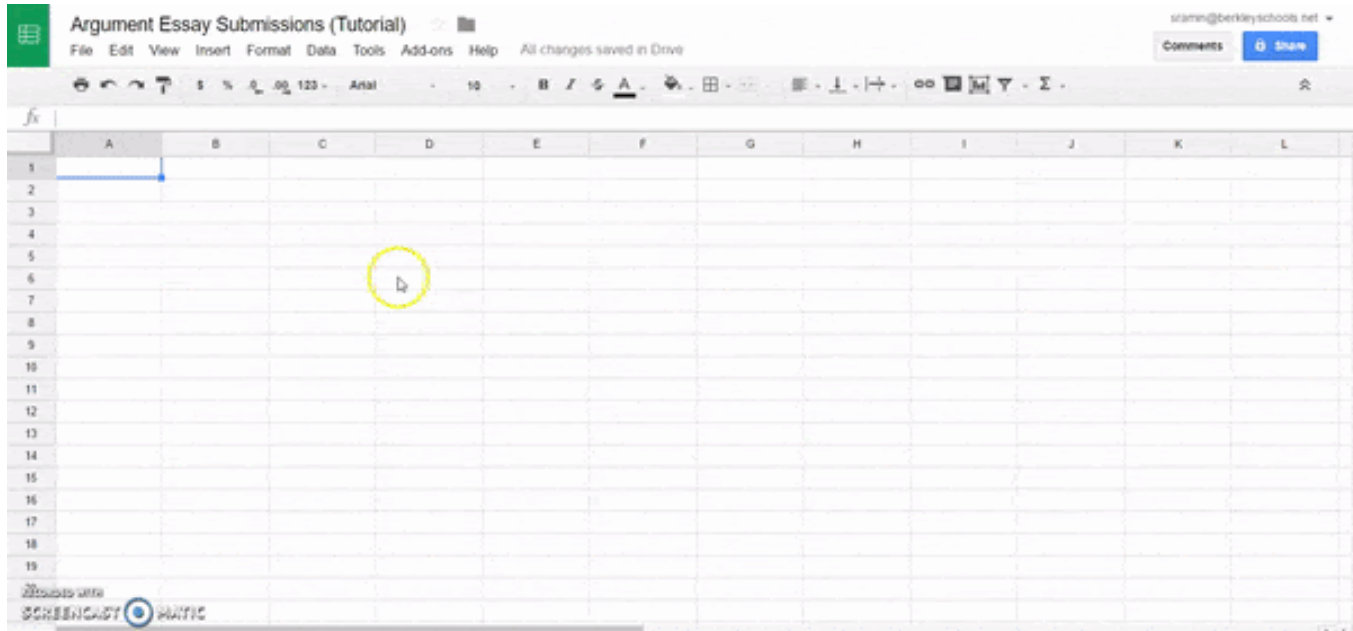

Figure 10 Doctopus adding process

4. A compatible Google Sheets rubric. See example below:

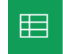

Argument Essay Rubric (Tutorial)

File Edit View Insert Format Data Tools Add-ons Help Last edit was yesterday at 2:41 PM

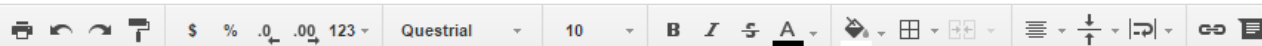

\begin{tabular}{|c|c|c|c|c|c|c|}
\hline \multirow[t]{2}{*}{$f_{x}$} & \multicolumn{6}{|c|}{ Point values in Row 1} \\
\hline & A & B & c & D & E & $\mathrm{F}$ \\
\hline 1 & & 10 & 8 & 6 & 4 & 0 \\
\hline 2 & Criterion A: Analyzing & \begin{tabular}{|c|} 
Gives detailed \\
justification of ideas \\
with a range of \\
examples and thorough \\
explanations; uses \\
accurate terminology. \\
(Evidence 8 \\
Explanation) \\
\end{tabular} & $\begin{array}{c}\text { Sufficiently justifies } \\
\text { ideas with examples } \\
\text { and explanations; uses } \\
\text { accurate terminology. } \\
\text { (Evidence } 8 \\
\text { Explanation) }\end{array}$ & $\begin{array}{l}\text { Justifies ideas with } \\
\text { some examples and } \\
\text { explanations, though } \\
\text { this may not be } \\
\text { consistent; uses some } \\
\text { terminology. (Evidence } \\
\text { \& Explanation) }\end{array}$ & \begin{tabular}{|} 
Rarely justifies opinions \\
and ideas with \\
examples or \\
explanation; uses little \\
or no terminology. \\
(Evidence 8 \\
Explanation)
\end{tabular} & $\begin{array}{l}\text { Does not reach } \\
\text { a standard } \\
\text { described by } \\
\text { any of the } \\
\text { descriptors. }\end{array}$ \\
\hline 3 & Criterion B: Organizing & $\begin{array}{l}\text { Makes sophisticated } \\
\text { use of organizational } \\
\text { structures that serve } \\
\text { the context and } \\
\text { intention effectively. } \\
\text { (Topic sentence, } \\
\text { transition words, } \\
\text { closing sentence) }\end{array}$ & $\begin{array}{l}\text { Makes competent use } \\
\text { of organizational } \\
\text { structures that serve } \\
\text { the context and } \\
\text { intention. (Topic } \\
\text { sentence, transition } \\
\text { words, closing } \\
\text { sentence) }\end{array}$ & $\begin{array}{l}\text { Makes adequate use of } \\
\text { organizational } \\
\text { structures that serve } \\
\text { the context and } \\
\text { intention. (Topic } \\
\text { sentence, transition } \\
\text { words, closing } \\
\text { sentence) }\end{array}$ & \begin{tabular}{|} 
Makes minimal use of \\
organizational \\
structures though these \\
may not always serve \\
the context and \\
intention. (Topic \\
sentence, transition \\
words, closing \\
sentence)
\end{tabular} & $\begin{array}{l}\text { Does not reach } \\
\text { a standard } \\
\text { described by } \\
\text { any of the } \\
\text { descriptors. }\end{array}$ \\
\hline
\end{tabular}

Rubric categories in Column A

Figure 11 The result of compatible

British, Jurnal Bahasa dan Sastra Inggris 
It makes teachers ease to construct groups to share assignments and announcements. Google Classroom can be a platform that makes learners become active participants. Furthermore, Nagele (2017) said that teachers can make effective lessons that are student-centered, interactive and memorable through Google Classroom, as it offers easy-to-use learning tools for students of all categories to work together.

\section{The Advantages of Google Classroom in ELT}

Many advantages can be obtained by applying Google Classroom for blended classes. In EFL environment where English is not used for everyday conversation, having Google Classroom as a supporting media to learn is very useful. Teacher can have conversation by using English at Google Classroom with students even they are not a school or campus. Robertson (2008) stated that Google Classroom provides students with an English online communicative environment to practice language skills and to develop their linguistic competence. Besides, Google Classroom is free application and no ads. Everyone can download it and it is simple to use. By not being overloaded with features, and offering learning aids like Quick Guides, FAQs, and lots of other support and help tools, Google Classroom is not difficult platform to get started with. Without advertisements appears, and a process for inviting and managing which students access which classes, it addresses the fundamental concerns of privacy and safety that are an issue with many other free tools on the Internet that are great for sharing content and social learning, but are not education-specific or particularly student-friendly (Wahls, 2013).

Lots of activities that we can do when the class is operated with Google Classroom. First, an announcement can be made. The teacher can provide class update announcements in this section. They can also attach files and materials to the class. Second, set up the assignment. This is Google Classroom's most significant functionality. The teacher must upload student assignments in a timely manner. Students can also download materials submitted by teachers in order to complete their mission. Third, ask the question. In this section, if allowed by the teacher, students may establish a question for discussion with the teacher or other

\section{British, Jurnal Bahasa dan Sastra Inggris}


students. Fourth, re-use post, teachers can use important posts such as notice, assignment, and query. Through that provides features that can facilitate collaborative learning between students.

Google Classroom has a range of facilities that support its users, some of them are a user-friendly, cost-free, secure cell phone and time-saving also it's very quick to use Google Classroom. Based on Janzen (2014), "The design of Google Classroom purposely simplifies the instructional interface and the options used to deliver and track assignments; communication with the entire course or individuals is also simplified by announcements, email and push notifications". The usability of Google Classroom is that it is easy to use. Students/teachers/parents/administrators can learn how to use the tool in a short period of time and, therefore, will be more likely to use it for class discussion, content management, and learning. In terms of accessibility, it is available to all users. Students /teachers/parents/ administrators can access the tool for using various devices with all types of browsers, from anywhere, anytime, anywhere. In terms of compatibility, Google Classroom is compatible with multiple devices and equipment. Since users will not have the same devices or equipment, it is important that the tool is flexible enough to be used with different devices or equipment.

\section{Google Classroom for EFL Learners}

A number of researchers investigated Google Classroom for ELT, some showed that Google Classroom is an effective tool to help teachers manage their classroom. The fisrt study is from Wijaya (2016). The study examines factors that affect Google Classroom use in support of lecturers. The study was carried out using the TAM (Technology Acceptance Model) to see the perception in the TAM that some students of STT Musi use Google Classroom. Students who already talk in Google Classroom are the demographics of this study. Data obtained by using purposive sampling to all students participating in the odd academic year 2014-2015 was allocated to up to 90 questionnaires. The results of this study have shown that Google Classroom use has a positive impact on 
perceived ease of use and expectations of perceived usefulness. These two perceptions also affect Google Classroom's use together.

In a second study (Shaharanee, Jamil, \& Rodzi, 2016), a study was conducted of the effectiveness of Google Classroom active training sessions on data mining as part of a decision-making program. A technology adoption model (TAM) was used to measure the effectiveness of learning activities. The target groups for this study were students who signed up for data mining, where the class was taught in a computer lab. To have a random method14, a simple random sample was applied when selecting a sample. The survey included questions about demographics, five predictor variables, and student satisfaction. Demographic issues related to gender, marital status, course, and average Internet access. To develop the questionnaire, Eastin \& LaRose developed an online self-efficacy scale, which was used as a reference. Altogether, 100 valid non-duplicate responses from students who received data collection were used in this study. The results showed that most students were satisfied with the Google Classroom software used in the classroom. Data analysis showed that all coefficients are above average. Comparative quality is especially good in the areas of usability, perceived usefulness, connectivity and interaction, literacy and user experience with active training in Google Classroom.

\section{Google Classroom and Writing}

One of the few experiments that shows that software is used to teach literature. Was the work in EFL background who performed by Quesada (2006). This research has shown that the online interactive platform Cyberl@b, which supports EFL researcher and III grade learners in a range of online exercises, is useful in ensuring that students practice writing in an engaging and independent manner alongside other language skills (Quesada, 2006, p. 1-25).

Nonetheless, experiments in other ways such as Ziad's one (2016) show that education apps like Google Classroom were used to teach written language in the past. In Hassan II University in Morocco, research was carried out in Ziad. It was designed to empirically investigate Moodle's actions with two-month students by illustrating the degree to which students embrace Moodle-hosted compositional

\section{British, Jurnal Bahasa dan Sastra Inggris}


research and assignments and Moodle increases their interaction with writing and teaching. For this purpose, the author has used three methods to collect information, such as Moodle interviews, a focus group and the event notes of Moodle. The study showed that Moodle was a useful learning tool for interactive composition, motivated students while they were studying and reading, and provided feedback. In fact, Ziad participants were strongly encouraged by the research, as the students concluded that the system performed better than other

platforms, apart from issues with registration. However, the perceptions of the students differed because some did not help to improve the writing of the learned tool until the instructor and the course part did not fulfill the required requirements. Other students attributed their achievements to a combination of factors, including activities based on Moodle, while other students directly related their progress to the platform used.

Following the previous report, it is important to investigate how Google Classroom was used to teach writing in EFL contexts. Sadly, this is not the view of any literature found, but we believe it is important to refer to studies that provide the reader with details on how Google Classroom was used in English Language Learning (ELL).

\section{Current and Future Challenges of Using Google Classroom}

Google classroom is simple to be operated and obtained. Despite, this platform has several challenges in its application on the classroom activity. Classroom application. Zaideh (2012) discusses greater problems, such as the negative impact of visual cues such as voice, inflection and body language provided in face-to-face communication. Stroud (2010) also lists some of the issues that may arise with Google Classrom such as low-income learners, the time that they spend in front of their computer and the ability to use it as a social networking site rather than as a learning instrument.

Since google classroom needs high speed of internet connection and wellconditioned computer with minimum specifications of multi-tasking device on supporting the flow of the learning activity or Smartphone to operate the app, this also becomes challenge in running online classroom. If a student does unable to

\section{British, Jurnal Bahasa dan Sastra Inggris}


access to computer or smartphone devices and also the Internet, they unable to use the tool interface. through the field condition not all areas of Indonesia have good internet connection and not all students have computer devices at home., it means the implementation of Google classroom will run with the supporting devices to the process of study. Grosscek (2009) stated that the alliance between Web.2 technologies and teaching-learning presents a number of challenges such as Internet connection requirements and the need for high digital skills.

In addition, Al-Asmari (2005) considers that EFL teaching expertise, the place of access and internet training were the most influential factors in the low level of use of Internet technologies. Further, Barnawi's study (2009) shows that there could be possible internal and external impediments to internet technology use in the classroom by the lack of technological resources and the imposition of traditional methods of education.

Many students are struggling with the crucial skills they have to work well in online learning, as they have not previously experienced online study. The ability of teachers to master digital support also affects Google Classroom implementation in combined learning. The main challenges contributing to the failure to fully exploit technology potential are teacher resistance, lack of training and restrictions on budget or sources according to Almaini (2013). With regards to Google Classrom, Bayne notes that the interface is too simple and dull, with a fairly lagging response time. Therefore, there is no text messaging functionality available. Students therefore cannot use Google Classroom to have their inner text. Stockwell (2008) and Motiwalla (2007) add that thin, time consuming screens and slow connection speeds can show the strength of a connection. The impact of online learning can create the students' interest in controlling their learning progression and more enthusiasm in class and out class. The applications of technology in learning attract many people to take its benefits for creating attractive and meaningful learning progression, on the other hand, many teachers need more struggle in the action of applying the ICT for several reasons. For example, they always deal with time estimation, lack of experience in using

\section{British, Jurnal Bahasa dan Sastra Inggris}


technology and their paradigms in applying it inside of the classroom. On the other side, online learning has many challenges.

\section{CONCLUSION AND SUGESSION}

Conducting traditional learning activity, through direct interaction inside of class is not enough for students in learning English for EFL learners by this time. Teacher should find another strategy to modify the learning, by this time the online platform is rising in popularity whisch enables teachers and student unity to have learning activity not only inside of classroom but outside classroom through indirect instructions. Google classroom is proved by another researcher as the one of the most used platforms to bypasses the traditional learning activity be an alternative online learning platform to be used in the classroom. Many researches presented that Google Classroom can be one of effective solutions for blended learning. By utilizing Google Classroom, teachers can post supporting materials, assignment, and quizzes online without having face to face interaction. Both programs will help to improve the quality of education both for teachers and students. The collaborative experience created by Google Classroom makes sure that information is no longer stored at locations identified by geography or can be exchanged and interpreted transparently, whereas learners can benefit from personal communication through classroom and face-to-Face experiences.

Because Google Classroom needs special skills and tools to do so, this software cannot be given to all teachers and students. Therefore, instructor resources should meet the needs of students, inspire students to learn English, promote student-centered learning and improve cooperative learning. In conclusion, Google Classroom can be used as the preferred blended education approach where classrooms, educators, students and parents collaborate together to meet learning goals.

\section{REFERENCES}

Al- Asmari, A. (2005). The Use of the Internet among EFL Teachers at the Collage of Technology in Saudi Arabia. Retrieved on November 7, 2015

\section{British, Jurnal Bahasa dan Sastra Inggris}


Almaini, Y. (2013). Issue in integrating information technology in learning and teaching EFL: The Saudi Experience. Merit Search Journal of Education and Review, 1 (5), 107-111

Barnawi, O. (2009). The Internet and EFL Collage Instruction: A Small-Scale Study of EFL College Teachers' Reactions. International Journal of Instructional Technology and Distance Learning, 6(6), 47-64

Beal, V. (2017). Google Classroom. Retrieved April 25, 2017, from Webopedia:http://www.webopedia.com/TERM/G/google-classroom.html

Grosseck, G. (2009). To use or not to use web 2.0 in higher education? ProcediaSocial and Behavioral Sciences, 1(1), 478-482

Kistow, B. (2011). Blended learning in a higher education: A study of graduate school of business, Trinidad and Tobago. Carribean Teaching Scholar Vol 12. November, $115-128$

Motiwalla, L. F. (2007). Mobile Learning: A Framework and Evaluation. Computers \& Education, 49, 581-596. http://dx.doi.org/10.1016/j.compedu.2005.10.011

Motiwalla, L. F. (2007). Mobile Learning: A Framework and Evaluation. $\begin{array}{llll}\text { Computers } & \& & \text { Education, } & 49,\end{array}$ http://dx.doi.org/10.1016/j.compedu.2005.10.011

Quesada, Allen. (2006). Cyberl@b: A platform for learning English in Costa Rican public high schools. Revista Actualidades Educativas en Educación, 6(3), 1-25. https://doi.org/10.15517/AIE.V6I3.9220

Shaharanee, I. N. M., Jamil, J. M., \& Rodzi, A. S. S. M. (2016). The application of Google Classroom as a tool for teaching and learning. Journal of Telecommunication, Electronic and Computer Engineering, 8(10), 5-8.

Stockwell, G. (2008). Investigating Learner Preparedness for and Usage Patterns of Mobile Learning. ReCALL, 20, 253-270. https://doi.org/10.1017/S0958344008000232

Stockwell, G. (2008). Investigating Learner Preparedness for and Usage Patterns of Mobile Learning. ReCALL, 20, 253-270. https://doi.org/10.1017/S0958344008000232

\section{British, Jurnal Bahasa dan Sastra Inggris}


Stroud, N. J. (2010). Polarization and partisan selective exposure. Journal of Communication, 60(3), 556-576. doi:10.1111/j.1460-2466.2010.01497.x

Stroud,C. (2010). Google Classroom: A White Paper. Connecting Technology \& Curriculum. Winthrop University. Retrieved on November 6, 2015 from http://coe.winthrop.edu/

Support Lecturers. The 5th ICIBA 2016, International Conference on 43 Information Technology and Engineering Application, (hal. 61-68). Palembang-Indonesia

Wijaya, A. (2016). Anlysis of Factors Affecting the Use of Google Classroom to Zaideh, A. (2012). The Use of Social Networking in Education: Challenges and Opportunities. World of Computer Science and Information Technology Journal (WCSIT),2(1),18-21.Retrieved from http://wcsit.org/pub/2012/vol.2.no.1/The\%20Use\%20of\%20Social\%20Netw orking\%20in\%20Education\%20Challenges\%20and\%20Opportunites.pdf

Ziad, Hicham. (2016). Technology-mediated ELT writing: Acceptance and engagement in an online Moodle course. Contemporary Educational Technology, 7(4), 314-330. 